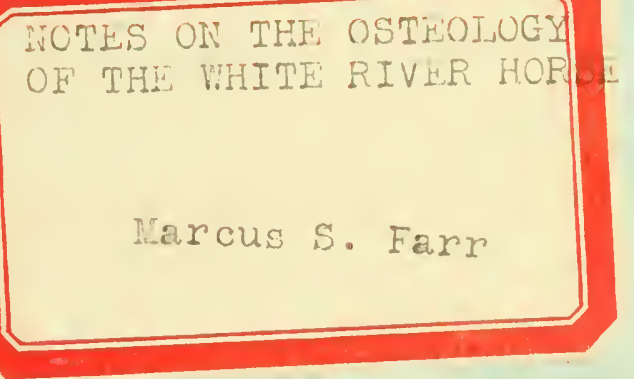




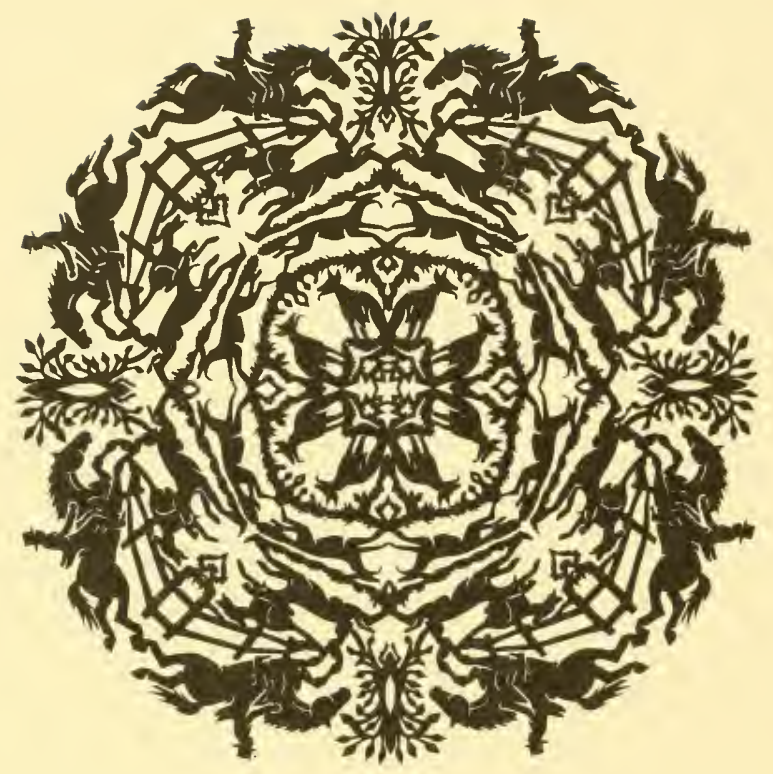

JOHN A.SEAVERNS

Webster Family Library of Veterinary Medicine Cummings School of Veterinary Medicine at Tufts University 200 Westboro Road North Grafton, MA 01536 


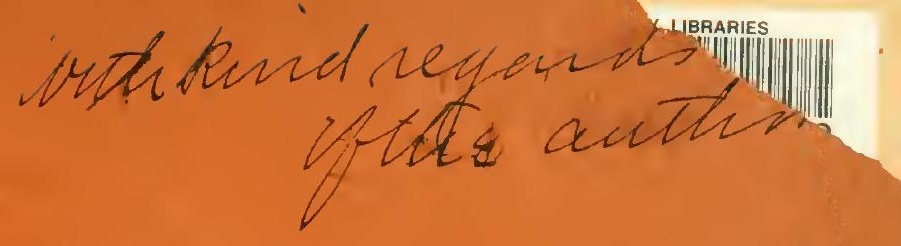

Notes on the Osteology of the White River Horses.

BY MARCUS S. FARR.

READ BEFORE THE AMERICAN PHILOSOPHICAL SOCIETY, MAY $15,1896$.

Reprinted, Sept. 7, 1896, from the Proo. Amer. Philos. Soc, Vol, xz8v. 

Notes on the Osteology of the White River Horses,

\author{
By Harcus S. Farr.
}

(Read bcfore the American Philosophical Society, Mry 15, 1896.)

\title{
MESOHIPPUS.
}

Althongh nearly half a century has elapsed since Mesolippus boirdi was first clescribed by Leidy, * our knowledge of its osteology has remained comparatirely incomplete, all the known material being limated to foot bones and more or less complete skulls. Most all of the skeletons that were found were badly broken up and only the larger and more perfeet bones were saved. IIolern methorls of collecting, essentially those introduced by Mr. J. B. Hatcher, thave revolutionizcd all this and now even the most (lelicate bones, though badly broken uls, are preserved as casily as the large bones were before collecting was done in a scientific manner.

Fortunate discoveries of more complete skeletons during the last three years have given us very much better material and now enable us to supplement the acconnts of $\boldsymbol{H}$. bairdi that have already been given, to add many new points on the osteology of the species and to offer a restoration which is an improvement on those heretofore offered.

Several species of Mesohippus have already been male on material from Nebraska, Dakota and Colorado. These have either been founded on a few teeth presenting peculiarities or on foot bones not associated with teeth. These species have not been generally accepted, and the founding of speries on such limited material especially in such a genus as Mesohippus which presents such a marked degree of individual variation does not seem justifiable and merely burlens science with useless synonyms. I have not seen the types upon which the various species.

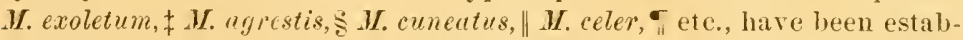
lished, but from the study of the individual variations in the many** specimens of $\boldsymbol{M}$. brircli studied by the writer it seems very evident that the species are not well grounded and that the peculiarities may be accounted for by the factor alrealy mentioned.

The discovery of the Protoceras beds and their recognition as a distinct subdivision of the White River formationstt marks a stage in the derelopment of the palæontology of this epoch.

* Leidy first described this species as Palæotherium bairdi, Proc. Acad. Nat. Sci., 18:0, p. 122.

† Curator of Vertebrate Palæontology in the College of New Jersey.

$\ddagger$ Cope, U. S. Geal. Survey of the Territories, 1873.

? Leidy, Rept. U. S. Geol. Sur. Terrs. (4to), i, p. 251, Pl. vii.

\| Cope, Palæontl. Bull., No. 16, p. T, August 20, 18 is.

"Tarsh, Am. Jour. Sci. and Arts, 1874, p. 251.

** Remains of neariy oné hundred individuals have been studied by the writer.

t+Wortman, On the Divisions of the White River, Bull. Am. Mus. Nat. Hist., Vul. v, pp.95106. 
The fuuna of the Protoceras beds is unique in many ways, especially in the number of new and bizarre forms that come in, some evidently by migration, while others are the direct descendants of the species of the underlying Oreodon beds.

These strata are interesting, as they form a transition to the later John Day beds, their famma being intermediate between the latter and that of the Oreodon beds.

A new speeies of horse has been found in this formation which helps very greatly in explaining the individual rariations of $\boldsymbol{M}$. bairdi, as many of these are seen to be attempts in the direction of $\mu$. intermedius, which is undoubtedy the direct descendant of the former. Besides these two species which are seen to stand in the direct relation of ancestor and descendant there is another species, $M$. copei, which occurs first in the strata of the Oreodon beds and is represented in the Protoceras beds by larger individnals.

Geologieal succession of the species:

Protoceras beds: $\boldsymbol{M}$. bairdi, H. copei, .M. intermedius.

Oreolon beds : $\boldsymbol{M}$. bairdi, $\boldsymbol{M}$. copei.

Titanotherium beds: $\boldsymbol{M}$. bairdi.

The genus Mesohippus occurs then in all the different horizons of the White River beds. In the Titanotherium beds it is usually represented only by fragmentary remains, which, however, are unmistakably those of $M$. bairli.

The Oreodon beds have yielded most of the best material. Through the whole extent of the fossiliferous strata of these beds, a vertical thickness of at least one hundred and eighty feet, remains of $\boldsymbol{M}$. buirdi are fairly abundant. Howerer, the remains are not well preserved, groups of teeth and the Jarger limb bones are common, while well-preserved portions of the skeleton are rare-a perfect skul] has never yet been found. Beside $M$. bairdi we get in the upper Oreodon beds a new spe cies which has been described as $\boldsymbol{M}$. copei. ${ }^{*}$ The Protoceras beds have yielded only fragmentary remans of $\boldsymbol{M}$. buirdi. This speeies does not represent the main line of descent during this epoch, but it is here taken up by $M$. intcrmedius while the former still persists as a side line. We also get $\boldsymbol{H}$. copei, which continues on from the Oreodon beds and is now represented by larger individuals.

Of $M$. bairdi nearly the entire skeleton is represented by material in the Princeton eollection.

The skull has been quite fully described by Leidy, $f$ and the skeleton has been the subject of an exhaustive paper by Prot. Scott, $\ddagger$ but when this paper was written the entire skeleton had not yet been found and the incisor teeth of upper series are the result of explorations of the summers of 1894 and 1895 , so some points in the description will be new.

* Osborn and Wortman, I'ull. Am. Mur., Vol. vii, pp. 356in35?.

†The Extinet Mammalian Funno of Dukota and Nebraska, Philadelphia, 1869.

$\ddagger$ Journ. of Morphology, Vol. พ, No. 3, December, 1891. 
Moreover the description of this species de novo is justifiable because we wish to trace the steps in the evolution of the horse as they can be followed in the horizons of the White River strata and must therefore have a description of one species as a standard for comparison.

It is the purpose of this paper to add some new points on the osteology of $M$. bairdi and to give a new, more aceurate and more complete restoration; to give a short deseription of $\boldsymbol{M}$. intermedius and $\boldsymbol{M}$. copei, and to show their relation to each other and to M. berirdi.

I must acknowledge my very great indebtedness to Prof. Sentt, who has given me so much assistance in the way of suggestion and criticism and whose kindly interest in my work has erer been an inspiration during my three years of graduate study in Princeton. To Mr. J. B. Hatcher $I$ am also rery much indebted for free access to collections and for kindly criticism and help and for much information on White liver mammals.

I must also extend my thanks to Prof, H. F. Oshorn and Dr. J. L. Wortman, of the American Museum, for permission to study some of their very beantiful material; also to the latter for valuable suggestions.

The drawings are by Mr. R. Weber, and add materially to the value of the paper.

\section{Tile Dextition}

The dental formula is I. $\frac{3}{3}, \mathrm{C} \cdot \frac{1}{1}, \mathrm{Pm}, \frac{4}{4}$, Mf $\frac{3}{3}$. The dentition is thus seen to be unreduced, and the specialization or modernization consists in the complexity of the last three premolars which are molariform and P1n. 2 is beginning to assume the elongate character, so marked in the living horse by the elongation of the anterior part of the external half of the tooth. The characters of the permanent teeth have alrealy heen describer by Leidy, * Osborn, $\nmid$ and Scott, t but very little las been writen concerning the milk dentition and the superior incisors have only very recently been found. Only two skulls are known bearing the upper incisors, nearly all the skulls that are discovered having the end of the very narrow snout broken off.

The inferior canine is the smallest of all the teeth ; it is suberect and conical, and there is a wide diastema between it and Pm. 1. The lower incisors are spatulate or chisel shaped and do not show any indication of a depression or pit. They have sharp cutting edges, and their innersurfaces are strongly concave. The first incisor is the longest $(i . e$, highest above alveolar border) and also the widest of the incisor series. I. 2 is smaller than I. 1, while I. 3 is the smallest of the incisor series. There is thus a decrease in size and length of incisors outwardly towarls the canine. The six incisors form an unbroken row.

* Ancient Fauna of Nibraska, pp. 70, 71 ; Extinct Mam. Fauna of Dak. and Nob., pp. 3r5$309,1869$.

† Bull. of Mus, of Comp. Zoül., Vol, xvi, pp. \&8, 8:.

f "Osteology of Mesohippus and Leptomeryx," Journ. of Morph., Vol. v, No. 3, pp. 303-305. 
The anterior border of the mandible is rounded and the teeth are arranged in the segment of a eircle.

The fourth lower premolar is wider transversely than any of the other teeth, while the posterior half of Pm. 3 is wider proportionately than any of the remaining teeth, with the exception of the former. Pm. 4 has a massireness not seen in the other lower teeth. Sometimes this is so marked that if the teeth were not found together they would in all probability be attributed to a larger individual. It had long heen supposed that the superior incisors were not pitted. Prof. Scott * has separated Mesohippus from Miohippus on the character of the upper incisors. A skull in the Princeton collection shows the upper incisors which seem to be pitted, but as they are so much worn a determination of their character is not possible. Osborn and Wortman $\uparrow$ have just described these teeth and through the kindness of these gentlemen I have been permitted to examine this beantifully preserved sknll. The two onter pairs of incisors show a distinet invagination, which is not, however, present on I. 1. Upper Pin. 1 is a small single-coned tooth, which has two distinct roots. The cingulum is well-developed on the inner side, enclosing a deep pocket. Anteriorly there is a tiny accessory conule. The corresponding tooth of the lower jaw is very small and inserted by only a single fang. Pm. 4 of the upper series is wider transversely than any of the other teeth.

\section{Succession of tile TeEtir.}

From all that can be observed the three large decituous molars first appear simultaneonsly in both jaws. The next tooth to appear is that which represents Pm. 1 of the permanent set. Nothing is known as to the time of appearance of the incisors and canines, but judging from analogy we may presume that they appear as ealy as the milk molars. A mandible of Mesohippus (No. 1110\%), with milk dentition and M. 1 of the permanent set, shows alveoli tor the three incisors and canine. The next tooth to appear (after persistent Pm. 1) is M. 1, which is sueceeded by II. 2. Next the temporary molars are replaced by the permanent premolars.

In the upper jaw these are replaced in the following order: Pm. 4, Pm. 3, Pm. 2 (Pm. 1 persisting in botl jaws). One specinen shows Pm. 4 almost ready to erupt, while Pm. 3 is rery much smaller and the germ of Pm. 2 is very feebly developed. The mode of succession in the lower jaw seems to follow the same order. In specimen No. 10995, M. 1 and M. 2 have appeared, and the germs of the permanent teeth are seen by picking away the bone and exposing loots of teeth, where the germ of Pm. 4 is seen to be better developed than that of P1n. 3. This also accords with the rate

* Trans. Amer. Phil. Soc., 18\$3, p. 79. In the light of present knowledge it seems best to abandon the genus Miohippus and to make the genus Mesohippus iuclude the John Day equines as well as the White River forms.

† Bull. An. Hus. Nat. Hist., Vol. vii, p. 353. 
of wear of teeth, as Pm. 4 is usually more worn by attrition than Pm. :3. After the deciduous teeth are replaced by those of the permanent set, M. 3 appears in both jaws.

It is not possible to tell from available material whether the incisors and canines are replaced or are persistent. In the later horse from the Equus beds, the incisors were certainly replaced, and the germ of canine is seen pierciug the jaw. The foramen, through which it is growing, is large, but it is not possible to determine whether it had a predecessor or represents a permanent canine which does not appear nntil the other teeth are dereloped. Chanrean* makes the statement that the canine persists and is not replaced in the horse. However, judging from analogy, we are quite safe in presuming that in .M. brirdiboth the incisors and canines had predecessors in the milk series.

\section{TIIE MiLK Dentition.}

The temporary dentition may be given in the following formula :

$$
\text { I. } \frac{3}{3} \text {, C. } \frac{1}{1}, \text { D. } \frac{4}{4} \text {. See Fig. } 1 \text {. }
$$

The tooth which represents Pm. 1 of the adult skull is not a true milk tooth, as it does not appear nutil the other teeth of the milk set are fully developed, and is not replaced as are the teeth of the temporary series. It may be considered a persistent milk tooth, as it las no predecessor, and then the dental formula will be as given above. If consiclered one of the permanent set, as there are ample reasons for doing, the molar formula will be: D. $\frac{3}{3}$.

The differences between the deciduons teeth and those of the permanent set are not due to any addition or reduction in the number of elements entering in to the formation of the teeth, but are due to the difference in the relative development of the elements in the two

FIG. 1.
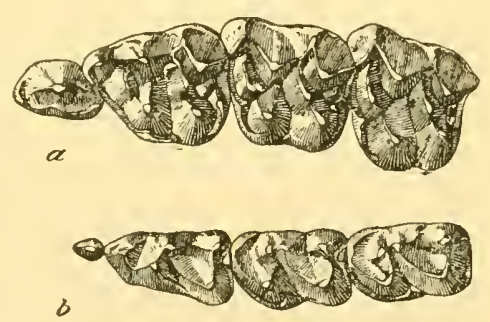

Milk Mola Ps of M. BaIrdi, 1.

$a$, superior series.

$b$, inferior series. sets. The diflerences ean best be described hy instituting a comparison between the two sets, and to do this it will be best to describe those of the permanent set and then show how the deciduous molars ditfer from them. The last two of the temporary set differ only in minnte detail from the corresponding teeth of the later set, but there is a fundamental difference between Pm. 2 of the permanent set and its predecessor in the milk series.

All of the premolar teeth, with the single exception of $\mathrm{Pm}$. 1, are molariform. Pm. 2 of both jaws presents some points of difference 
from the other teeth, while the simple character of Pm. 1 has already been sufficiently commented upon. The last lower molar, as in so many forms, differs from the others in the presence of an additional less well-developed lobe situated posteriorly. The lower molars and Pms. 3 and 4 have oblong, quadrate crowns, with an outer pair of fore and aft principal lobes, and an inner pair of secondary lohes connate with them. "The principal lobes of the crown are slightly oblique in their relative position, angularly conrex and sloping externally, concavely excavated internally and are acutely crescentoid at their summit. Of the inner secondary lobes, the anterior is much the larger, and is pramidal in form with a twin pointed summit." This claracter is olservable only in teeth that are not worn excessively and disappears as the summits of the crown are worn off in mastication. "The anterointemal cusp springs from the crown at the conjunction of the principal lobes and is continuous with their contignous crowns. The posterior of the secontary lobes is conical and springs from the cown in conjunction with the back horn of the posterior prineipal lobe. The front horn of the anterior principal lobe curves inward, downward and backward to the base internally of the anterior secondary lobe. A basal ridge (or cingulum) nearly continuous bounds the crowns of the lower molars externally. Posteriorly it rises inwart and teminates in a tubercle springing from the conjunction of the two posterior lobes." Pm. 2 deserves a slight mention in passing. In the lower jaw the posterior half of this tooth is an exact eopy of the corresponding part of any of the succeeding premolars or molars. One half of the antero-internal hobe is present as usual, but this alone forms all of what corresponds to this lobe in the succeeding teeth. Anterior to this and externally there is another lobe more nearly median in position. This is connected with the former by a ridge and the two together form a lobe which is very different from any of the others. Interior to this and connate with it is a small Jobe on the internal surfare of the tooth. The decilnous tooth diflers from the permanent one in that in the former the two anterior lobes are more distinct from each other and from the other lobes, so that we seem to have five lobes in this footh. Again in the earlier set this tooth has a greater antero-posterior extent than any of the other teeth, almost equaling in length M. 3 of the permanent set, which lats the alditional lobe. In the permanent set P'm. 2 is even shorter antero-posteriorly than the succeding tooth in the mremolar series. In the milk set D. 4 has the posterior half narrower than the anterior half. In D. 3 both halves of tooth are of approximately the same width. While, in the permanent premolar series the posterior half of the tooth is always the wiler, while in the molar series the reverse condition obtains. The cingulum is not so well developed on the deciduous nolars as on the corresponding teeth of the permanent set. It is not cleveloped on the external surfice of the posterior lohe as in the permanent tooth, hut is present on the posterior border of tooth where it ends in a tubercle. The cingulum 
is well developed on the antero-external bohe of Ds. 3 and 4 , even better than on the corresponding permanent tooth. It has lately been ealled to $\mathrm{m} y$ attention that the cingulum varies in the individual with the nourishment, well-nourished individuals having it better developed than those poorly nourished, but the recurrence in many indiviluals of the character as given above prechdes the possibility of its being an indivichal variation. The antero-internal cusp is wirter antero-posteriorly in the temporary teeth than in the permanent set and the bifid character of this cusp is more marked in the former. All the lower milk teeth are narrower and longer antero-posteriorly than the permanent teeth. Both the upper and lower molars of the deciduous set are of not nearly so great vertical length as those of the later series.

\section{THE UPPER MOLARS.}

Premolars 2, 3 and 4 are molariform and Pm. 2 is beginning to assume the elongate character which is so much emphasized in the living horse. The six molars (i.e., molars and molariform premolars) are nearly alike in size and form. "They have square crowns, wider transversely than broad antero-posteriorly and both these measurements greatly exceed the length. The crowns eonsist of three pairs of lobes-an onter and an inner pair of principal lobes and a much smaller pair situated between them, the secondary or accessory lobes. 'The outer lobes are demi-conoidal and form at their junction a namow buttress externally. A stronger buttress bounds the fore part of the anterior of the two lobes. A teudency to the development of a buttress is seen also at the back purt of the posterior of these lobes. The buttresses expand and are conjoined at the bottom of the crown, forming together a pair of arches bounding the external surfaces of the outer lobes. These surfaces are nearly flat and are divided by a conspicuous median ridge. The inner surfaces of the outer lobes are prominently or almost angularly convex. The inner lobes of the crown are simply conical, wider transversely than fore and aft aud with the anterior slightly larger than the posterior. The median lobes are not more than half the size of the principal ones and appear as prominent folds curving outwardly from the inner lobes to the anterior face of the outer lobes. Elentents of a basal ridge exist at the fore and aft parts of the crown and at the outlet of the valley separating the inner lobes. In the interval posteriorly between the back inner and outer lohes there exists a tubercle which in association with the contiguous portions of the basal ridge assumes the dignity of a sublobe." In Pm. 1 the anterior buttress is more distinct or separate than in the other molars, though it is not so large. The anterior of the median cusps is larger than the posterior, except in Pm. 2, which is peculiar in this as in so many other respects.

The teeth of the temporary set present the following diflerences from those of the permanent set deseribed above:

1. The eusp situated between the outer and inner posterior lobes, the 
so-called hypostyle, is less well developed in the deciduous molars than in those of the permanent set.

2. D. 2 is much larger, more elongate antero-posteriorly, more complex, the antero-externa] buttress being mueh larger and more distinct in the earlier set. It is so large that it might almost be considered a fifth principal lobe.

3. The median accessory lobes (5 and 6 ) are more conical than in the permanent set, where they are somewhat appressed. These lobes in the early set are separated by a distinct noteh from the internal lobes.

4. The transverse ridges are more nearly confluent with the outer wall of tooth in most of specimens in the temporary set. There is, however, great individual variation in regard to this character.

5. In the adult skull all the molars and molariform premolars are much wider transversely than antero-posteriorly. The decidnous teeth are more nearly square, the two diameters being subequal.

6. The buttress on the antero-external lobe of tooth, the parastyle, is better developed in the milk set.

7. D. 2 is the longest tooth of the milk series and is beginning $t o$ assume the elongate character of this tooth in the modern horse, while the corresponding tooth of the permanent set is smaller than any of the other molar teeth.

8. All the temporary teeth are shorter in vertical height than those of the permanent set.

\section{The Vertebral Columa.}

The cervical and dorsal vertebra have already been minutely described. The lumbar vertebre are almost certainly five in number. The centra are large and are reniform in shape, being wide transrersely and not having the more nearly circular outline of the median dorsal vertebre. All of the lumbars, with the exception of the last, have their centra strongly keeled. The centra are moderately opisthocolous. The interlocking character of the vertebra through the zygapophyses is marked, The neural spines are long, transversely compressed and narrow and have considerable antero-posterior extent. They are all directed forward at an angle. The transverse processes are well developed and widely expanded. The intervertebral foramina perforate the bases of the newral arches, and are not merely notches in the ends of the nemral arch as they are in the anterior vertebre of the column. The last two lumbar vertehre have their transverse processes expanded almost as widely as those of the first sacral itself, and the transverse processes of the fonth lumbar abut against those of the fifth, while the latter bears on the posterior surface of the transverse processes deep concarities for the corresponding surfaces of the anterior end of sacrum. In analogous condition is seen in Equus, and in old individuals the last two lumburs are very frequently immovably coössified. The last lumbar las the spine more nearly erect than that of the penultimate lumbar vertebra. 
A very remarkable character of the lumbar vertebre is that they have spines which are nearly, if not quite, as high as those of the anterion dorsal region, which in the horse are so much elongated. In the latter the lumbars have spines which are lower, more nearly erect, of more considerable antero-posterior extent proportionately and are much les: compressed transwersely.

\section{TIIE SACREM.}

The sacrum of $\boldsymbol{M}$. bairdi, as in most of the Ungulata, consists of one broad vertebra joining the ilia, followed by a series of narower ones. gradually diminishing in width anchylosed to it behind. These latter diminish in width very gradnally. In living Ungulates the mumber of vertebre entering into the formation of the sacrum varies with the age of the individual and also varies in individuals of the same age.

In the specimen which belongs with the pelvis described below there are six vertebre. This is the most perfeet sacrum of $\boldsymbol{M}$. bairdi yet found, and the component vertebre are fortmuately well preserved and hardly crushed at all (see Fig. ? and Plate xiii).

The first or true sacral vertebra is greatly expanded transversely and bears large articular surfaces for the ilia.

Anteriorly there are large convex facets which fit in to the corresponding concavities in the transverse processes of the last lumbar vertebra. The first sacral has a low and comparatively wide centrum. The spine is very high, very much compressed laterally, as are all the spinous processes of Fic. 2. the vertebrie, and is directed strongly forward, while in the modern horse it is almost vertical. The five succeeding vertebra have transverse processes which are not so widely expanded, the centra are very much depressed and the neural arehes are low and gradually decrease in height posteriorly. This, of conse, conditions the size of the neural canal, which in this region is very much attenuated. The expanded transverse processes of the contiguons rertebre are all united, so that they form a narrow elongate plate. The spine of the second sacral is gone, but the others are all preservel. That of the third is almost vertical, while the spines of the three posterior sacrals all slope backward at a decided angle. There is thus a very abrupt transition in the direction of the inclination of the spines from the first in which the spine projects forward to three in which the process is almost vertical. The plate formed by the anchylosis of the centra and transverse processes of the rertebre is concave inferiorly or curves downward posterior to first sacral. The sacrum presents inferiorly the foramina for the five pairs of sacral 
nerves, the inferior sacral formina, while above we also find laterally hetween the neural arches of the contiguous vertebre the five pairs of the superior sacral foramina.

Measurements of the Sacrum.

Length............................... 116

Extreme with $\ldots \ldots \ldots \ldots \ldots \ldots \ldots \ldots \ldots \ldots \ldots \ldots \ldots, 64$

Width third sacral ...................... 23

Width fouth do. ........................ 21.5

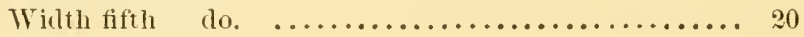

Tire Caudals.

The few caudal vertebræ preserved are sufficient to give us a general idea of the character of the tail. The first caudal has very widely expanded transverse processes similar to those of the posterior sacral region; the centrum is oval and the neural arches arise at a very great angle enclosing a high and very narrow nemal canal. The transverse processes are of considerable antero-posterior extent, hut do not equal the length of the centrum in width as they do in the posterior vertebra of the sacral region. 1t is not possible to determine how many of the caudal vertebre had complete arches, because of incomplete material. In Equus* the spine of the neural arch is bifid in the second caulal and the arches are incomplete on the third. The transverse processes gradually become shorter, the neural arches more rudimentary and are finally lost, and all we have is a cylinder of hone with very rudimentary proresses which gradually diminish in size. Among the caudals preserved is one of these last, in which all the processes are very feebly developed. All the vertebre of the tail are in greneral like those of the horse, and in them, as in most all of the anatomical features, we see a foresharlowing of what the future horse is going to be.

\section{The Sternum.}

With the almost complete skeleton figured in the restoration of $\boldsymbol{H}$. bairdi in Plate xiii are preserved three segments of the sternum. These are the xiphisternm and two segments of the mesosternm. The former is very much more elongate and not so high as the other divisions of the sternm. Anteriorly it is about twice as broad as high, while posteriorly it is rery much flattened. The free border is thin and rounded with irregular surface, showing where cartilage was attached. Laterally the body of this segment as of all the other is concare. The superior borter is almost plane, while the inferior is slightly concave, or the free end may be said to project slightly down ward.

The next segment in front of the above that is preserved is very evidently the penultimate segment of the mesosternum. This is very differeat in shape from the xiphisterum. The posterior portion is wide and

* No. 338, Princeton Coll. 
low, while anteriorly it is much narower and higher. Both superior and inferior surfaces are plane and the sides are very strongly concave. The third segment is evidently the first division of the mesostermum, and is ligh and long and almost trihedral in cross-section. These separate segments of the sternum are not coössified, and the surfaces for the artienlation of the sternal eartilages of ribs are not well shown. From the portions of sternum deseribed above we are safe in assuming that there were at least six segments in the sternum of $\boldsymbol{M}$. bairdi.

\section{The Scapula.}

The nearly complete skeleton from which the restoration given herewith is made fortunately las the seapula very well preserved, and this reveals quite an unexpected charaeter, viz., the presence of a distinct acromion. The only other Perissodactyl known to have retained this process is Pachynolophus (Orohippus) of the Bridger Eocene. Marsh * has described it in this genus as follows: "The scapula has a prominent acromial process, which is compressed and decurved as in some Carnivora." Iesohippus is the only Perissodactyl known to have retained this process until Oligocene times, and it has thus been retained longer by the horses than by any other family of this order. It is possible that future diseoveries may also reveal the presence of a elavicle in Mesohippus, as it has been diseorered in the contemporary Oreodon culbertsoni, $\nmid$ and in the latter genus it persists until Deep River times, where it has been found by Prof. Seott $\neq$ in the form wheh he las ealled Mesoreodon. The possession by both Mesohippus and Pachynolophus of this process would seem to justify us in regarding the latter as the Bridger ancestor of the horse line of which Mesohippus is the White River representative. The scapula is wider in proportion to its height than that of Equus. The anterior margin is very thin and strongly

Fig. 3.

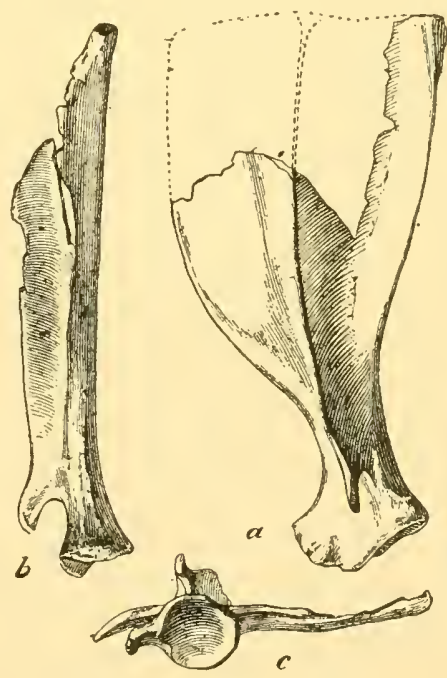

SCAPULA OF M. BATRDI, $3 / 8$.

$a$, from outside.

$\checkmark$, from behind.

c, from below.

*Amer. Jour. Sc. and Arts, Series 3, VoI vii, 1S74, p. 247

tA specimen in the museum of the University of Chicago reveals the presence of the clavicle.

†Trans. Amer. Philos. Soc., Vol. xvii, p. 136. 
convex, while the posterior border is only slightly rounded and is very much thickened, a character that has been retained by the Equidæ, Tylopoda, Pecora and Suina, but has been lost in the Tapiridge and Rhinocerotidx. 'Thespine of the seapula is rery high and seems to extend nearly or' quite to the vertebral border. It is much nearer to the anterior border than the posterior, thus making the preseapular fossa much smaller than the postscapular.

The spine becomes gradually more prominent towards the middle portion, at which point it seems to have been highest and the edge was here strongly retroverted as in Tapirus and Rhinoceros. From this point it decreases in height towards the vertebral border.

The acromion is styliform in shape, is compressed antero-posteriorly and extends outward and downward, but does not quite reach the level of the glenoid carity. It resembles in shape that of the eamel and llama, but differs from these in that they are more slender, more nearly perpendicular and extend nearly or quite to the level of the glenoid carity. The process gradually tapers towards the free end, which is somewhat rounded. The neck of the seapula is very much constricted and is comparatively long. The glenoid cavity is quite deeply excavated, is very slightly elongate antero-posteriorly and has a well-defined rim.

The coracoid process is strong, curves inwardly and is slightly retroverted.

$$
\text { Measurements of Scapula. M. }
$$

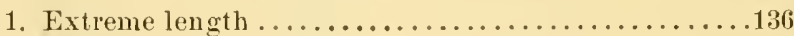

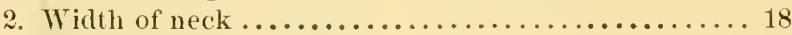

3. Width of distal end.................... 32

4. Extreme width........................ 74

5. Width at highest point of spine ............. 74

6. Width of supra-spinous fossa here $\ldots \ldots \ldots \ldots \ldots \ldots .25$

7. Width of infra-spinous fossi here........... 45

\section{Measurements of Scapula of Equus.* Mм.}

1. Extreme length.......................... 414

2. Width of neek ........................

3. Width of distal end......................

4. Extreme width...........................

5. Wilth at highest point of spine ............. 146

(j. Width of supra-spinous fossa here............ 48

7. Width of infra-spinous fossa here............ 93

These measurements show the seapula of $\boldsymbol{H}$. brimdi to have been proportionately more expanded superiorly than that of the horse and at the same time the neck is proportionately more contracted than in the latter.

*No. 338, I'rinceton Coll. 
The Pelis (No. 11376).

The pelvis is equine in all its characters and very much like that of the modern horse with some characteristic points of difference. The specimen deserihed below is the first pelvis of Mesohippus bairdi that has ever been found showing all the characters, being almost perfect. See Fig. 4, and Plate xiii. It was discovered by Mr. J. W. Gidley during the past sumFig. 4. mer in the lower Oreodon beds.

The most striking difference between the pelvis of $H$. bairdi and that of the loorse is that the former is narrower in proportion to its leugth than that of Equus.

The great breadth of the pelvis anteriorly in the latter is owing to the very great lateral expansion of the ilia, while in the earlier genus they are proportionately less widely expanded. The ilia directly in front of the acetabulum are slender in their proportions and expand more gradually than in the horse, so that they are longer in proportion to their widtli than in the latter. The bone is

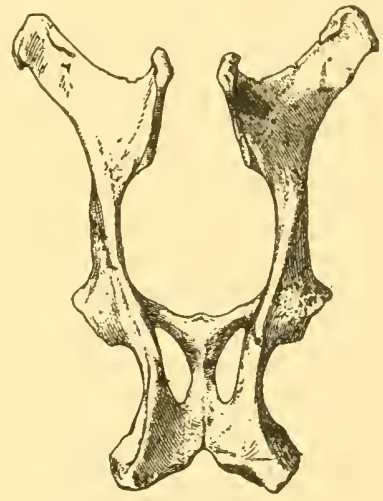

PELYIS OF M. BAIRDI, 1/4. widely expanded superiorly and the angle above the point of articulation of the ilim with the sacrum curves upward and outward, and the free end is thickened and somewhat rugose. This upward and outward expansion of angle makes the external border of superior aspect of the ilium concare. The crest is more slender and elongate comparatively than in Equus and is strongly everted. The border of the ilium between the angle and the crest is very thin and strongly concare. The whole anterior expanded portion is thin except along the outer or lower border. The posterior border of the angle above the point of articulation of the sacrum is also slightly thickened. The sacral border of the ilium is large and extends high above the articular facet for the sacral vertebrie forming the angle. The ilia as well as the long axis of pelvis are directed downward at an angle from the vertebral column. The acetabulum is an elongate oval in shape and its borders are elevated and well-defined. The border is incomplete below owing to the encroachment of the pit for the ligamentum teres on the acetabular fossa. This is less emphasized, however, than in the horse. The pit for the liganentum teres is quite deep.

The ischium is straight and on a line with the long axis of the ilium. The bone curves outwardly posteriorly, but does not curve upward as in the horse. The posterior border is expanded and thickened ontwardly where it ends in a stout process, the tuberosity of the ischium. The internal border posteriorly is deflected towards the median line and meets 
its fellow of the opposite side at this point forming part of the symphysis. Above the acetabulum the border of bone is high and rounded, but is not sharp and angular as in the horse. The obturator foramen in the pelvis of the latter is rounded and shorter in proportion to its width than in I. buirdi, being only slightly elongate, while in the species under consideration the foramen is narow and very much elongated, the length equaling twice the breadth. This conditions the shape of the posterior portion of ischimm, which in $\boldsymbol{M}$. bairdi does not extend fir back of the posterior border of obturator foramen, while in Equus the ischium forms a large expanded plate posterior to the obturator foramen.

The pubis is elongate, flattened from above downwarl and irregularly triangular in shape. The portion of pubis nearest the acetabulum is almost round in cross-section, while in the horse the corresponding portion, as in fact the entire pubis, is very much more flattened. It meets its fellow of the opposite side in the median line forming the anterior part of the symphysis with the bases of the triangles applied together The symphysis is formed by both pubes and ischia conjointly, the former constituting the anterior and larger part while the ischia form the posterior part. Fusion of the pubes is so complete that no trace of a suture remains, while the ischia are not anchylosed together. The anterior part of the symphysis is flattened in the form of a large plate, which bears inferiorly in the median line a prominent spine. All the processes for muscular attachments are less strong and rugose than in the horse. The pelvic foramen (or cavity) is longer in proportion to the brealth in M. bairdithan in the horse, heing a little longer than broad, while in the latter the pelvic outlet is broader than long. In Mesohippus the length (or vertical height) is about $6.5 \mathrm{~mm}$. and the breadth $60 \mathrm{~mm}$., while in the horse the reverse condition obtains and we find a length of only $174 \mathrm{~mm}$. as compared with a width of $199 \mathrm{~mm}$.*

Other measurements of the pelvis are as follows:

1. Extreme length ................

2. Length of acetabular cavity .............. 26

3. Length of symphysis.................. 63

4. Extreme width of ischia................ it

5. Width at acetabulum................... 102

6. From top of angle to outer point of erest......... 89

7. From anterior border of acetabulum to point midway between angle and crest. . ............. it

Restoration of M. BAIRDI (Pl. XIMI).

In 18\%9, Prof. Marsh,t in giving the genealogy of the horse, brought out the fact that the chief moditications through which the horse passes in its evolution are the following :

1. Progressive increase in the length of teeth and in their eomplexity,

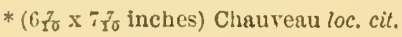
†Am. Jour. Sci, Vol, xrii, p. 497. 
from a very short-erowned tooth with distinct roots, to one witlı very long crown in which roots are not tormed till animal becomes adult.

2. The gradual lengthening of the limb bones with the suppression of the lateral digits and the concentrition of the growth force in metapodial iii, produeing ultimately a monodactyl foot from a pentadactyl ancestor.

3. The continued reduction of una and fibula and their ultimate analescence with the radius and tibia.

4. Gradual increase in size from an animal not larger than a fox up to the modern horse.

Mesohippus buirdi is an interesting intermediate stage in the evolution of the horse; though primitive in many respects, it had already made considerable advance over its Uinta predecessor.

The restoration here given is made from a nearly perfect skeleton which enables us to make some improvements on the one already giren, * which, howerer, was as good as conld be made with the material then a vailable.

The lumbar vertebræ, sacrum, pelvis and a few of the posterior dorsals are from another individual redueed to proportion. Part of the skull is also restored from another specimen.

Mesohippus occupies a position abont midway in the line of descent of the horse series. It presents the following advances over its Bridger predecessor, Pachynolophus.

1. The teeth are longer (vertically) and more complex, the intermediate eusps are better developed, and the transverse ridges are likewise better developed and more nearly confluent with outer wall of tooth.

2. The lateral metapodials are more reduced comparatively, and metapodial ii is much larger. In the Briclger form the phalanges of the fifth cligit are present, but $\boldsymbol{M}$. bairdi has lost these.

3. Both the ulna and fibula are more reduced than in the earlier form

4. In M. bairdi, Pms. 2-4 are molariform, while in Pachynolophus Pm. 4 only is molariform and is smaller than true molars. Epihippus, the Uinta representative of the series, has Pms. 3 and 4 molariform, and this is the only generic distinction between the Bridger and Linta genera.

The orbit is commencing to retreat, though it is still over the molars, the anterior border being directly over the posterior half of $\mathbf{M}$. 1 . In the horse it is situated posterior to molar series, and we can trace a gradual transition in the position of orbit up through the different genera from Mesohippus to Equus. This shifting backward of the orbit brings about a gradual elongation of the facial region of the skull. The alveolar border of the maxillaries is low, this of course being associated with low-crowned, short-looted teeth.

From the character of the teeth we may judge of the life habits of the animal. The teeth of the modern horse have very long crowns

* Journ, of Morph., Vol. v, No. 3, p. 337. 
(hypsodont), grow from persistent pulps and do not form distinct roots until the animal is quite old, not until a length of crown is attained which under normal conditions will afford sufficient grinding surface for an arerage lifetime. As the teeth wear off by attrition the loss is leplaced by growth, and growth and wear proceed pari-passu until the animal becomes adult.

The little Mesohippus, with its short-crowned (brachyodont) teeth, inserted by distinct roots, must therefore have fed on succulent plants that grew in swampy, marshy land-as if subjected to wear necessitated hy the mastication of the hard, silicious grasses of Miocene times, the teeth would soon have worn out entirely and the anmal would have succumbed to starration. In most of the specimens found the teeth are only moderately abraided.

The feet, too, being tritlactyl are adapted to progression along the bozy shore of rivers or to swampy, marshy ground as the toes would spread and thus support the animal in the mud, while the monodactyl foot of the horse is preëminently adapted for rapid locomotion over the grassy plains. This would seem to prove that the lite habits of the animal have changed very greatly during its evolution. Many of the White River animals were adapted by their anatomical structure to life in swamps. Some were at least semi-aquatic in their habits, as is denoted by the position of the posterior nares, which in some forms are removed very far backwarl, e.g., Ancodus.

The skull is equine in its characters, but is still quite small and the facial region is short. The orbit is not enclosed behind.

The neck is long, and, as in the horse, these vertebra are larger than those of the dorsal region of the column. The processes are not so massive as in Equns, but are quite as complex and are very well developed. The spines of the dorsal vertebre are not so high as we should expect, and very evidently $\boldsymbol{M}$. bairdi did not have any great elevation of the anterior dorsal region. The modern horse is much higher at the withers than at the haunches. The spines of the lumbar vertebre are very high and incline forward at quite an angle. There is a very abrupt transition in height of spines from the first sacral, which has a very high spine to third sacral, which has a very much lower spine, though it is still much compressed laterally. Six rertebre take part in the formation of the sacrum. The centra of the first few caudals are flat with widle transverse processes, but these, as well as all the other processes, gradually become suppressed and the nenral arehes disappear so) that the lower caudals are merely cylinders of bone. It is impossible to determine the exact number of rertebre taking part in the formation of the tail, but it is fair to imagine that it hal one at least as long pro portionately as the horse.

The scapula is remarkable for the persistence of the acromion process, in which character it is unique among all Perissodactyls, with the exception of Pachynolophus (Orohippus) of the Bridger. The spine is better 
Proceedings Amer، Philos, Soc,

Nol, XXXY, No, I5 1 Plate XIII,

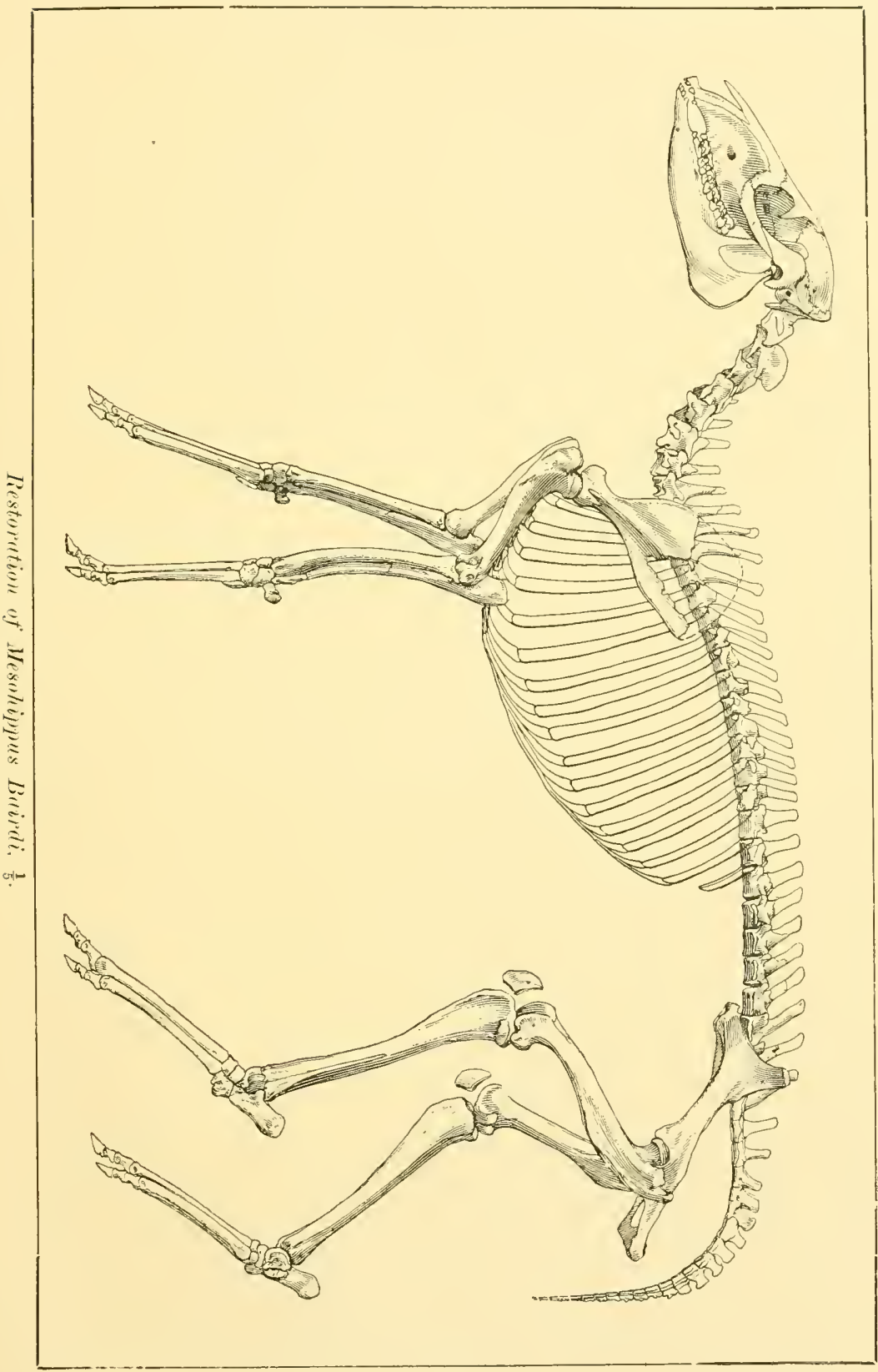



developed, the bone is lower and broader, the neck is more constricted proportionately than in the horse. In the latter the anterior horder of the scapula is not rounded as in Mesolippus. The ulna is very much reduced in $\boldsymbol{H}$. bairdi, and the radius is enlarged to sustain the weight of body. The ulna is distinct from the radius through the whole of its $\mathrm{cx}$ tent, the two bones not being coössified even in old individuals. Below the proximal half the bone is much compressed and tapers rapidly toward the distal end. This gives it a frail character so that it is almost always broken away in fossilization, and only recently have specimens been found which permit an accurate determination of its character. The distal end is not compressed as it is higher up, but is round in crosssection and bears a facet for the cunciform. A rudiment of the fifth metacarpal persists. All the metacarpals and their plalanges are somewhat shorter and less massive than the metatarsals and the phalanges of the hind foot. The pelris is thoroughly equine and yet differs in many minor characters from that of the horse. It is narrower in proportion to its length than that of the latter. The ilia expand less abruptly, the crest is narrower and more elongate proportionately, and the ischia do not bend upward posteriorly as in the horse, but are in a straight line with the long axis of the ilia. The obturator foramen is more elongate and narrower transversely, and the pelvic outlet is higher and narrower proportionately than in the modern equine.

The fibula was complete in $\boldsymbol{M}$. bairli; was very much reduced in size and was coössified with the tibia. The proximal end is quite small, the shaft is filiform, while the distal end alone is quite large and forms the external malleolus articulating with the astragalus, and in extreme extension of the foot also with the calcaneum. The fibula remains complete until John Day times, for in Mesohippus (Anchitherium) prostans Cope from this formation it is retained in its entirety.

The hind limbs are much longer than the fore limbs, more so proportionately than in the horse, so that the rump must have been much elevated above the withers if the different elements of the limb were not very much more flexed on each other than would seem justıfiable, judging from recent animals. Many of the White River animals had a curved arched back instead of a straight back as in the horse, e.g., Iyanodon, Leptomeryx, etc. This is shown by the character of the centra of the vertebræ. The great individual variations met with in $\boldsymbol{M}$. brirdi have been noticel by every investigator who has studied a series of specinens of this species. These variations are principally in the limbs and teeth. Some of these have already been noted. In several individuals the three cuneiforms of tarsus are all coössified into a single compound cuneiform. Usually the ento- and meso-cuneiforms are united.

There is usually a moderately large contact of metatarsal iii with the cuboid, this latter usually extending below the level of the ectocuneiform, so that all contact of metatarsal iii with cuboid is lateral. In some specimens there is a slight extension outwardly of the proximal 
end of M. iii and the cuboid is slightly shorter, so that it articulates with the distal end of cuboid instead of being confined to mere lateral contact. The antero-internal angle of cuboid is accordingly somewhat modified in shape to correspond with the changed outline of metapodial iii. This is a tendency in the direction of $\boldsymbol{M}$. intermedius of the Protoceras beds, and a foreshadowing of the condition in the modern horse which has such a large facet on the cuboid for the widely expanded proximatl end of metatarsal iii. Between this condition and that where there is only lateral contact with the cuboid, we find all the intermediate stages. A gain, there is a great deal of variation in the relative proportions of the lateral digits to each other, and in the relation they bear to the median digit. Sometimes the Jateral digits are not much reduced and are subequal in size, while again we find the lateral digits very much reduced, and Mt. iv, at least proximally, is usually larger than MIt. ii.

In $M$. bairdi usually there is no confluence of posterior transverse crest with the outer wall of tooth, usually separated from it by a large interval, but occasionally we get an individual in which there is actual confluence, and we get all stages intermediate between these two extremes. We get individuals where the interval between outer end of transverse crest and outer wall is less, and, again, others in which there is a small process jutting inward from the point of union of onter lobes, toward the transverse crest, these separated by a rery small interval, and then we get complete confluence. These highly specialized forms were, of course, not ancestral, but were prematurely modernized and left no descendants. However, these individuals most specialized occur highest up in the beds, showing that these variations are attempts in the way of evolution.

\section{Mesohippus Copei.}

This is a new species of horse from the White River, which has just been described by Osborn and Wortman. * In their description of the type no specific characters other than those of size are given, by which it may be distinguished from the two other species from this horizon. This species was founded upon a complete lalf of a pelvis, femur, tibia and part of a hind foot, together with a median metatarsal and one lateral metatarsal of another individual, a collateral type. "These remains indicate an animal of much larger size than those of $\boldsymbol{M}$. intermedius, and, so far as we know, is the largest horse of the White River epoch, even larger than Mesohippus (Anchitherium) prostans of the John Day." The species is undoubtedly well founded, but the material in the $\mathrm{\Lambda m}$. Museum did not permit the establishment of good specific characters. I have studied carefully the material upon which the species is founded and have been able to refer some material in the Princeton Collection to this species. This material consists of the distal end of a

* Bull Am. Mus., Vol, vii, pp. 352-353. 
femur, tibia and almost complete hind foot, and enables me to give some further characters of the species. $M$. eopei differs from $U$. bairdi in the following respects: (1) The lateral metapodials curve outwarlly quite sharply distally and the toes were thus more spreading than in $\boldsymbol{H}$. buirdi (see Fig. 5). (2) The meso-cuneiform is proportionately less deep than the ecto-cuneiform than in $\boldsymbol{M}$. bairdi. (3) The carina or median keel of the clistal end of metatarsal iii, which in the smaller species is almost entirely confined to the plantar surface of the bone, in $M$. copei extenrls fur up in the dorsal surfice of the distal end of the bone. (4) The lateral metapodials are comparatively shorter than the median metapodial, so much so that the ungual phalanges could searcely have been functional at all, and this form had progressed farther toward monodactylism than any other known form from the White River. (5) The combined depth of the navicular and ecto-cuneiform was greater than in $\boldsymbol{V}$. bcrirdi, and greatly exceeded that of $\boldsymbol{M}$. intermedius. (6) The cuboid did not extend below the level of the ecto-cuneiform. Metatarsal iii was borne by the latter alone and did not extend over on the cuboid, so that anteriorly there is no contact of these two bones either lateral or distal as in both the other species.

The tibia is about one and one-half times as long as that of $\boldsymbol{M}$. bairdi, and is proportionately much stouter.

The shaft is very long, even longer than that of the John Day species, but is more slender, and scen from the side it presents the characteristic sigmoid curve. The cnemial crest is very high, curves slightly outward and has the usual tendinal sulcus on its outer border. It extends farther down on the shaft than in $\boldsymbol{M}$. bairdi. The proximal surface is very much more rugose than in the latter. The femoral facets slope downward and backward at quite an angle. The outer facet is convex antero-posteriorly and concave transversely. The inner facet is concave anteroposteriorly and convex transversely. The distal end of tibia is turned slightly outward. The distal end of tibia and fibula together are proportionately widler than those of $\boldsymbol{M}$. bairdi. The facets for the trochlear surface of astragalus are deeply incised, are oblique in position and are separated by a high intertrochlear riclge.

The proximal end of the fibula is not preserved, but the very large distal end and a portion of the shaft persists. Rugosities on the outer border of tibia indicate that it was complete and closely applied to the latter. The portion of the shaft preserved is very much reduced. The expanded distal end forms the external malleolus and bears the two usual facets.

The tarsus presents striking differences from that of $\boldsymbol{H}$. bairdi, and can best be described by instituting a comparison between it and the latter.

The calcaneum is stouter and more massive, but has about the same relative proportions as in $\boldsymbol{H}$. bairdi. The tuber calcis is large and rugose for the insertion of the tendo Achillis. The tuberosity is quite high 
with its inferior border slightly convex. The upper border is broken

Fig. 5.

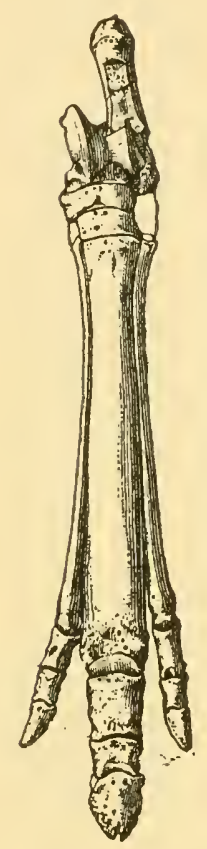

LEFT FOOT OF M. COPEI, $1 / 4$. away. The tuberosity is much thicker and more massive than in the smaller species, where all the bones are gracefully shaped. The sustentaculum is very strongly developed and bears a large facet for the astragalus, which facet is elongately oval in shape. The crest formed by the superior or ectal astragalar facet is broken ofl so that its character cannot be determined. 'There is a slight prolongation of this facet antero-externally which is somewhat more emphasized than in the smaller species. The inferior facet is near the distal end, and is the smallest of all the facets of calcaneum, and does not extend far back from the distal end-elongate in shape. The facet for the cuboid is large, occupying all the distal end of the bone which is more obliquely truncated than usual. The shape is triangular with the apex towards the sustentaculum.

The astragalus is merely an enlarged copy of that of $\boldsymbol{M}$. bairdi with some differences of detail. It is proportionately broader. The trochlea is more widely open and the condyles are higher and thicker. The neck is of about the same relative proportions as in M. bairdi. The internal condyle as nsual is the longer of the two and anteriorly slightly overhangs the navicular fucet while in the smaller species it does not quite reach it. The outer condyle is very much shorter than the inner and is separated from the navicular facet by quite an interval.

The navicular is a flat bone, is wide transverscly and seems proportionately higher than in $\boldsymbol{M}$. bairdi.

The proximal articular surface is strongly concave antero-posteriorly for the corresponding surface of astragalus. Posteriorly there are two elevations on the inner and outer borders respectively, between which is a wide and shallow depression for the projection on the inferior margin of distal surfuce of the astragalus. The external margin of this latter projects strongly downward, extending around the outer edge of navicular. These two characters make a very close interlocking joint so that there is scarcely any direct lateral movement possible. This interlocking is not quite so complete, however, as in $\boldsymbol{M}$. baird $i$, as in this latter the external margin of inferior surface of astragalus extends farther down on outside border of navicular. This outside projecting borler is in the form of a erest which is placel obliquely on bone and limits the direction of the movement of the two bones taking part in this articulation on each other to an oblique motion. The distal surface of bone presents a large triangular fucet for ecto-cunei- 
form. Coalescing with apex of above is a facet extending up on posterior border of bone, which articulates with cuboid. On the proximal surface there is a small facet on the antero-external corner of bone, which articulates with the caleaneum by a small facet just above the inferior astragalar facet and which seems to be a part of the latter, but on close examination proves to be a distinct ficet. In $\boldsymbol{H}$. bairdi the navieular just touches the ealcaneum, but does not have such distinctly marked facets. This character is seen in some individuals, but in all observed specimens the contact is smaller.

The ecto-cuneiform is high and massive, the breadth being twice the lieight. The proximal facet for navicular is concave, both antero-posteriorly and transversely. The inferior (or distal) facet is concave in both these directions. On the external side it abuts against the cuboid, and this latter seems to have been just equal in length to the combined length of ecto-cuneiform and navicular. It bears no facet either lateral or proximal for metatarsal iv.

The coössified ento- and meso-cuneiforms show an emphasized condition of that of $M$. bairdi, in that the tendeney of the distal row of tarsal bones to form a closed circle is more marked here. The portion representing meso-cuneiform bears most all of the proximal end of metatarsal ii. The ento-cuneiform is high and compressed transversely and curves strongly backward and around towards the other side of foot. On its inferior surface it bears a facet at its point of contact with metatarsal ii.

The metatarsus of $\boldsymbol{M}$. bairdi exhibits the following charaeters: (1) The cuboid which bears metatarsal iv extends down below the external cuneiform which bears M. ii. (2) The meso-cuneiform does not quite reach to level of the ecto-cuneiform. From this it results that $M$. iv does not quite reach up to level of M. iii, while M. ii reaches abore the latter. In $\boldsymbol{M}$. copei, M. iv extends quite u] to the level of M. iii, while the meso-cuneiform is not so deep proportionately as in the smaller species. Metatarsal iv is proximally much less reduced than M. ii, hut tapers to about the same size distally. It is borne entirely by cuboid. The disproportion in size of the proximal ends of the two lateral metapodials ean hardly be more than an inclividual character, as we find all degrees of difference in the relative sizes of the two lateral digits in the smaller species.

In some specimens the two lateral digits are of the same size, in others subequal with the irth slightly the larger and in others this digit is very much larger than ii. One individual exhibits the very peculiar character of having the lateral metapodials of the same size on one foot, while in the opposite foot the fourth metatarsal is much larger than the second.

Metatarsal ii is slightly less reduced than in the average individual of I. bairdi. Proximally it bears a large concave facet for the meso-cuneiform and posteriorly there is a small facet by which it abuts against the inferior retroverted edge of the ento-cuneiform. This latter extends 
both above and below the meso-cuneiform and conditions the shape of the heas of II. ii, about one-half of the proximal surface being supported by the meso-cuneiform. Posterior to this facet the proximal surface slopes abruptly downward and presents the above-mentioned facet. Abont two-fifths of the internal surfuce of ecto-cuneiform is taken up with a facet for metatarsal ii, which in $\boldsymbol{M}$. bairdi extends upward proportionately less on the ecto-cuneiform. The shaft is of about the same dimensions proportionately as in $\boldsymbol{H}$. buirdi and was elosely applied to I. ii proximally, but both the lateral metapodials curve outward distally. The distal end is merely an enlarged copy of that of the smaller species, is high and compressed and the median keel is strongly developed. Metatarsal iii bears abont the same relation to the lateral metatarsals in size as in $\boldsymbol{M}$. bairdi. In the latter we have a distinct facet on M. iii, either lateral or proximal for the cuboid, but in the new species I. iii does not tonch the cuboid and the only facet on exterior surface of the proximal end is that for M. iv. It is borne entirely by the ectocuneiform and is quite large in proportion to the size of the lateral digits and supports nearly all the weight and receives most of the impacts and strains of the foot. The distal end is somewhat wider than the proximal end. M. iii is quite a little longer than the lateral metatarsals, more so than in $\boldsymbol{H}$. bairdi. All the plalanges are slightly more massive proportionately than in the smaller species.

The pelvis in the Am. Mus. Collection referred to $\boldsymbol{M}$. copei, I do not regard as Mesolippus at all because it is too much specialized in its own way to belong to a White River equine. It differs very much from that of $M$. brirdi and in some respects is more specialized than that of the modern horse. If the reference to $\boldsymbol{\mu}$. copei is correct, we have in this species a very aberrant side line of the horse series. The pelvis under discussion differs from that of $\boldsymbol{H}$. bairdi in the following respects: (1) The ilium expands very abruptly, almost directly in front of the acetabulum, while in $\boldsymbol{M}$. bairdi it expands very gradually and begins its expansion a long way in front of the acetabulnm (see Pl. XIII and Fig. 4). (2) The angle of the ilimm in $M$. bairdi and of all the known equines is sharp, but in this specimen it is rery much rounded. (3) The erest is broad and stout instead of being narrow and elongate as in $\boldsymbol{M}$. buirdi. (4) The border between angle and crest is rery much less concave than in $\boldsymbol{M}$. bairdi and the horse. (5) The border of bone above acetabulum is drawn out into a sharp crest even more pronounced than in the recent horse. (6) The acetabulum is round as in Hyracodon, not elongate as in $\boldsymbol{M}$. bairdi and the horse. (i) The ohturator foramen is broader in proportion to its length than in $\boldsymbol{K}$. bairdi. (8) The ischia turn upward at an angle posteriorly almost as much as in the horse, while in M. bairdi the ischinm is in a straight line with the long axis of the ilium and does not turn up posteriorly. In view of these great diflerences I cannot regard the reference to $\boldsymbol{I}$. cope $\boldsymbol{i}$ as correct.

In the American Musenm there are a series of lumbar vertebre which 
are too large for $\boldsymbol{H}$. intermedius, and their provisional reference to H. copei is justifiable. These are rery like those of $\boldsymbol{H}$. bairdi, but much larger and more massive. The provisional reference of the two premolars described with the type is also justifiable, as they are too large to pertain to any other known speeies of horse from the White River. Leaving the pelvis out as questionable, we may say that the remains indieate a very large equine agreeing with $\boldsymbol{H}$. bairdi in most of its claracters and yet specialized in its own way so that it is a little off the line of equine descent though most probably developed from $\boldsymbol{M}$. bairdi.

\section{Measurements of $\boldsymbol{M}$. copei.}

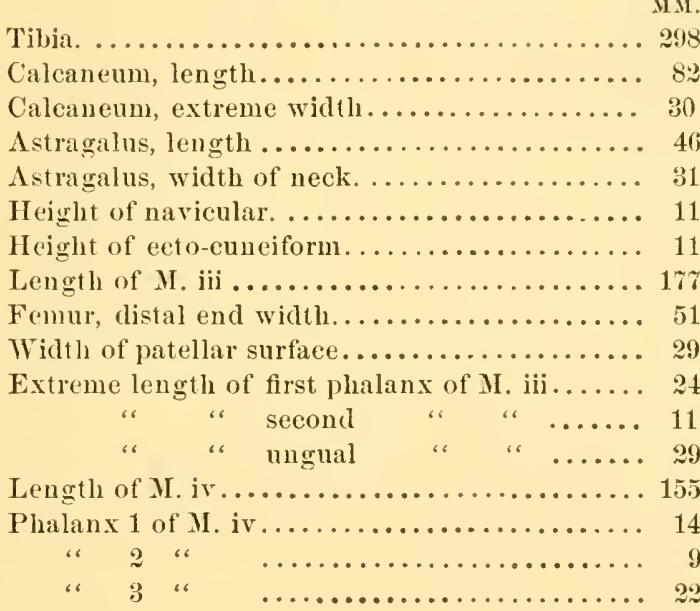

MII.

313

189

\section{MESOIIPPUS INTERMEDIUS O, and W.}

$\boldsymbol{M}$. intermedius, as the name indicates, stands intermediate between II. bairdi of the Oreodon beds and Mesohippus (Anchitherium) prestans of the John Day. It oceurs in the Protoceras beds. It is a strange and interesting fact that $\boldsymbol{M}$. bairdi continued on into the time of the Protoceras beds after having given rise to the two species.* A careful study of the prineipal characters of $\boldsymbol{M}$. intermedius brings out very strongly its relation to the preceding and succeeding species. In all these points it is seen to stand directly intermediate between M. Gairdi and Ncsolippus (Anchitherium) prestans of the John Day. In the light of present knowledge there can he no doubt that $\boldsymbol{M}$. bairdi is the direet ancestor of the modern horse, and by the study of the indiridual variations of the

* A remarkable instance of the persistence of an ancestral type is seen in the Loup Fork. Here Protohippus, a form with long-crowned, cement-covered molars, represents the main line of equine descent, while right alongside of it there is a much smaller spc. cies of $\boldsymbol{M}$. bairdi tyje which Cope has called Anchtherium uttimum. This form has short. crowned molars, without cement. 
former we can trace a tendency toward the establishment of the $M$. in termedius trpe.

The skull of $\boldsymbol{M}$. intermedius is much more equine in character than that of $M$. bairdi. It presents the following differences which may be looked upon as modernizations: (1) Increase in length, size and in general proportions. The largest skull of $\boldsymbol{M}$. bairdi observed measures 218 $\mathbf{m m}$., while that of $\boldsymbol{M}$. intermedius measures $280 \mathrm{~mm}$. (2) The upper incisors are all pitted (see Fig. 6), while in the smaller species only the

Fig. 6.

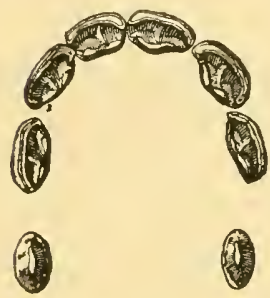

SEPERIOR INCISORS AND CANINE OF M. INTERMEDIUS, $\frac{2}{1}$. two onter pairs have the enamel invagination. (3) The facial region of the skull is more elongate and the orbit is shifted backward. In $\boldsymbol{M}$. bairdi the anterior border of orbit is over M. 1 ; in $\boldsymbol{M}$. intermedius it is over interval between Ms. 2 and 3. (4) The diastema between Pm. 1 and the canine is proportionately greater in the larger species.

The canine has a well-developed cingulum on its internal surface. This is the foreshadowing of the cupping, as the pit in an incisor tooth is formed by the cingulum, which rises up on the internal border of the tooth to enclose the depression. Teeth have been observed from the lower Oreodon beds which have a strongly developed cingulum anticipating the development of the pit. (5) The occiput is slightly more overhanging in the larger species. (6) The aveolar border of the jaw is better developed and higher in $\boldsymbol{M}$. intermetius. This, of course, is correlated with larger teeth, with longer roots. (7) The postorbital processes are better dereloped, more nearly enclosing the orbit. (8) There is in $\boldsymbol{M}$. intermedius a large deep antorbital fossa or depression occupying nearly all of the lateral wall of skull and extending forward almost to Pm. 1. (9) The teeth of the molar series are much larger, longer and more specialized than those of $\boldsymbol{M}$. bairdi. These differences, which have been given by Osborn and Wortman in their deseription, are: (a) "The internal cingulum of Pm. 1 is more strongly developed and a distinct basin is formed. (b) In the second upper premolar, the parastyle or antero-external buttress is considerahly larger than in $M$. bairdi and gives to the crown an incipient triangular shape. (c) The midrib of the external lobes is better developed than in $M$. bairdi, and the postero-transverse crest is more nearly confluenced with outer wall of tooth."

Length of Molar-Premolar Series.

M. bairdi... 73.5 M. intermedius....97 M. prostans... 112.5

Molar Series.

Premolar Series. 


\section{The Milk Dentition.}

In the Princeton Collection there is a skull bearing the temporary dentition (No. 11168). In the young skull the anterior border of the orbit is just between D. 4 and M. 1, so that as growth takes place the orbit is forced to retreat by the elongation of the facial region of the skull, as in the adult skull the anterior borter of the orbit is over the interval between molars 2 and 3 . The milk teeth agree in all essential points with those of $\boldsymbol{H}$. bairdi.

Measurements of the Superior Milk Teeth. MM.

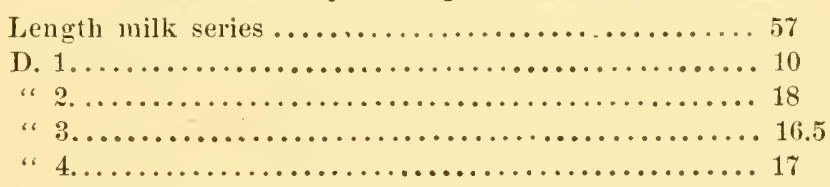

The lower teeth of the deciduous set agree in all their characters, ex cept size, with those of $\boldsymbol{M}$. bairdi.

There is nothing noteworthy about the vertebra except their increase in size over those of $\boldsymbol{M}$. bairdi. The limbs bear the same general proportions as in the smaller species. The seapula is higher and narrower proportionately than in $\boldsymbol{M}$. bairdi. All the limb bones are characterized by being much longer than in the smaller species. The ulna is not more reduced distally than in $M$. bairdi, and is distinct from the radius throughout. The shaft is compressed laterally and is very slender, but distally it is stouter and has a large facet for the cuneiform. Proximally the olecranon is more massive than in $\boldsymbol{M}$. bairdi. The radius is very large and is fast becoming the important bone of forearm. The earpus presents no important diflerences from that of the smaller species. It is still high and narrow. A rudiment of the fifth metacarpal still persists, but is not so elongate as in $\boldsymbol{M}$. buirdi, but is shorter and stonter and on the way to disappearing. The lateral digits are usually more flattened than in the smaller species but are not more reduced, the distal ends being even more massive proportionately. The ungual phalanges of the lateral digits are loug, narrow and sharply pointed at the ends. That of metacarpal iii is proportionately wider than that of $\boldsymbol{H}$. bairdi.

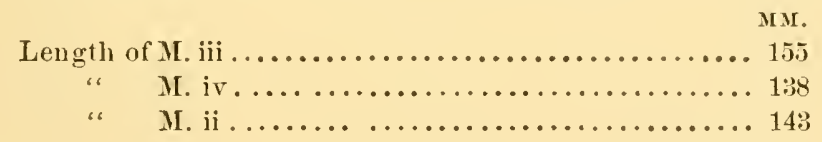

The ribs are characterized by their length and extreme slenderness, those of the median dorsal region being especially long, not much flattened, being almost round in cross-section. The pelvis presents few characters that are new. The ilia expand even more gradually than in H. bairdi. The angle rises up in a pointed process. The crest is partly 
broken away so that all its characters cannot be determined. The border of bone above the acetabulum is rounded and not sharp. The ischia turn upward slightly posteriorly and form more of a plate posterior to the obturator foramen posteriorly than in the smaller species. The sacrum has five vertebre entering into its formation. The spines of the lumbars are still very high, but they have a more considerable anteroposterior extent proportionately than in $\boldsymbol{M}$. bairdi. The femur has a massive proximal end, the great trochanter being lower and more massice than we usually see it in Mesohippus, but this may in part he due to the fact that our skeleton is of a young animal.* The tibia of $\boldsymbol{M}$. intermedius is somewhat stouter in proportion to its length than that of $\boldsymbol{M}$. bairdi. The cnemial crest is strong and well developed. As usual, there is a large fossa external to the enemial crest. The fibula is still complete and is distinet from tibia. The proximal end is quite small and the shatt is rery much reduced, while the distal end is quite large, forming the external nulleolus to articulate with astragalus and with calcaneum in extreme extension. Both proximal and distal ends, as well as the shaft, are closely applied to the tibia, but are not coössified with it. The tarsus of $\boldsymbol{M}$. intermedius is more modern than that of $\boldsymbol{M}$. bairdi in that the tarsus is wider and lower, which is a step in the direction of the modern horse. The calcanem is very long, the tuber proportionately longer than in $\boldsymbol{M}$. bairdi, and is quite stout with an expanded free end. The cuboidal facet is long and narrow, ahost ereseentic in shape and extends downward and inward to the sustentaculum. There is quite a large fibular facet. The astragalus is broader and the trochlea is not so deeply incised as in $M$. bairdi, though it is distinctly equine in pattern. The two condyles of the astragalus are very unequal in size. The inner almost always overlaps the navieular facet, while the external is separated from it hy a long interval. In $\boldsymbol{M}$. bairdi the internal condyle never reaches the navicular surface. The navieular is much flatter and lower, as is also the ecto-cuneiform, than in $\boldsymbol{M}$. bairdi. The cuboid is also shortened, just equaling the height of the two contiguous bones. metatarsal iii extends over on cuboid.

This is another modernization. There is a distinct facet on the calcaneum for the mavicular. There is a much more complete interlocking of the tarsal bones in $\boldsymbol{M}$. intermedius than in any other White River horse. The ento-cuneiform as usual is high, extending both above and below the meso-cuneiform which is still not so deep as the ecto-cuneiform. On its posterior surface it bears a distinct facet for the cuboid with which it unites in forming the small facet for M. iv. Metatarsal iv is usually less recluced proximally than M. ii, but tapers to about the same size distally. This demonstrates the manner in which the reduction of digits takes place in the family. We know from $\boldsymbol{M}$. brirdi that II. i first disappealed and afterward M. v. The condition in M. intermedius indicates that $\mathbf{M}$. ii would next become rudimentary, and then II. iv. In the horse where the lateral metapodials are mere splint

* This may also account for the fact that fibula is not coüssified with tibia. 
bones and closely applied to M. iii, M. iv is still larger than M. if proximally.

The inter-relationships of these three species may be expressed by the following diagram :

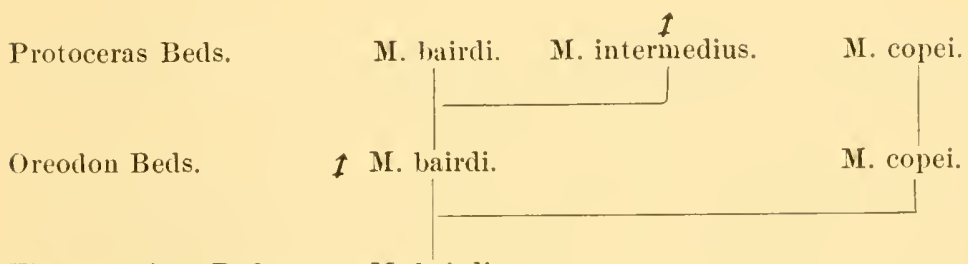

Titanotherium Beds. I M. bairdi.

The phylogeny of the horse series as it is now generally understood may be given as follows:

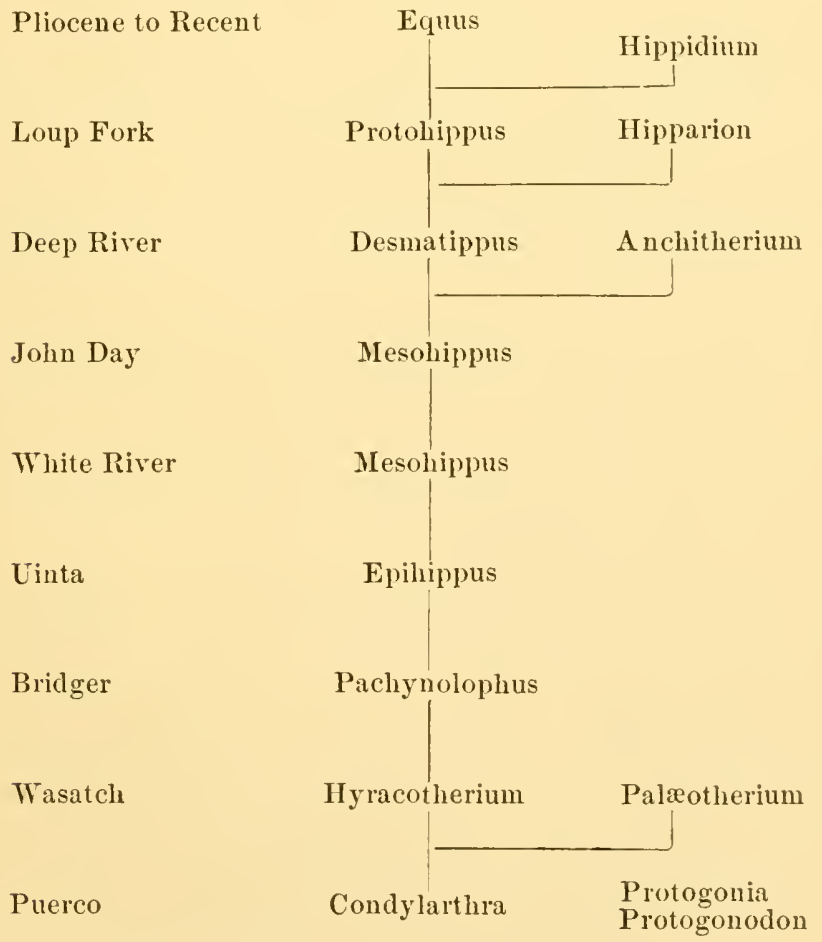

I Represents the line of descent. 


\section{Literature.}

1. Chauveau : Anatomy of the Domesticated Animals. New York, 1873.

2. Cope, E. D.: Tertiary Vertebrata. Rep. U. S. Geol. and Geog. Survey of the Terrs., Vol. iii.

3. - Preliminary Report on the Vertebrate Palæontology of the Llano Estacado. Geol. Survey of Texas, 4th Ann. Rept.

4. - Origin of the Fittest. New York, 1886.

5. - The Hard Parts of the Mammalia. Journal of Morphology, Vol. iii, pp. 137-27\%.

6. The Perissodactyla. American Naturalist, 1887, p. 985.

7. - Report on the Vertebrate Palæontology of Colorado. U.S. Geol. Survey of the Terrs., 1873.

8. Dana, J. D.: Manual of Geology. New York, 1894.

9. Flower, W. H.: Osteology of the Mammalia. London, 1885.

10. Flower, W. H., and Lydekker, R.: Mammals Living and Extinct. London, 1891.

11. Hatcher, J. B.: The Titanotherium Beds. American Naturalist, 1893.

12. Huxley, T. H.: A natomy of the Vertebrated Animals. New York (London), 1871.

13. Kowalewsky, W.: Sur l'A nchitherium Aurelianense et sur l'histoire palæontologique des Chevaux. Mem. de l'Ae. imp. St. Petersb., $\mathrm{xx}, 18$ \%3.

14. Leidy, Jos.: Ancient Fauna of Nebraska. Smithson. Contrib., 1852.

15. - Extinct Mam. Fauna of Dak. and Neb. Philadelphia, 1869.

16. Contributions to the Extinct Vertebrate Fauna of the Western Territories. P. 251, Pl. vii, Rep't I, U. S. Geol. Survey Terrs.

17. - Proc. Acad. Nat. Seiences of Pliladelplia, 1850, p. 122.

18. Marsh, O. C.: Polydactyle Horses, Recent and Extinet. Amer. Journ. Sc., 1879, Vol. xvii.

19. _ Recent Polydactyle Horses. Amer. Journ. Sc., 1892, Vol. xliii.

20. - Notice of New Equine Mammals from the Tertiary. Amer. Journ. Sc., vii, 1874 , p. 247.

21. - Notice of New Tertiary Mammals. Amer. Jouru. Sc., Vol, ix, pp. 239-250.

22. - Introduction and Succession of Vertebrate Life in America. Amer. Journ. Sc., Vol. xiv, p. 337.

23. Osborn, H. F.: The Rise of the Mammalia in North America. Proc. Amer. Asso. Adv. Sc., Vol, xlii, 1893.

24. - Preliminary Account of the Fossil Mammals from the White River and Loup Fork Formations. Bull. Museum Comp. Zoöl. Cambridge, Vol. xvi. 
25. - Mammalia of the Uinta Formation. Pt. iii : The Perissodactyla. Pt. iv: The Evolution of the Uugulate Foot. Trans. Aner. Philos. Soc., 1889.

26. Osborn, H.F., and Wortman, J. L.: Fossil Mammals of the Lower Miocene White River Beds. Bull. Am. Mus., Vol. vi, pl, 199-288.

27. - Perissodactyls of the Lower Miocene White River Beds. Bull. Am. Yus, Vol, vii, pp. 343-375.

28. Schlosser, M.: Beiträge zur Kenntuiss der Stammesgeschiehte der Huftliere. Morplıologisches Jahrbuch, 1886, Bd. xii.

29. Scott, W. B.: On the Osteology of Mesolippus and Leptomeryx. Journ. of Morph., Vol, v, No, 3.

30. - Evolution of the Prenolar Teetl in Mammals. Proc. Acad. Nat. Sci., Philadelphia, 1892.

31. - Manmalia of the Deep River Beds. Trans. Amer. Philos. Soc, Vol. xvii.

32. Wortman, J. L.: On the Divisions of the White River or Lower Miocene of Dakota. Bull. Am. Mus. Nat. Hist., Vol. v, pp. 95-106.

33. Zittel, K.: Handbuch der Palæontologie. Band iv: Mammalia. München und Leipzig, 1893.

REPRINTED SEPT. 7, 1896, FROM PROC. AMER PHILOS. SOC. VOL. XXXV. 



Webster Family Library of Veterinary Medicine Cummings School of Veterinary Medicine at Tufts University 
